\title{
Temporal and spatial changes in small mammal communities in a disturbed mountain forest
}

\author{
Ladislav Hlôška ${ }^{1 *}$, Miroslav Saniga ${ }^{2,3}$, Gabriela Chovancová $^{4}$, Barbara Chovancová $^{4}$, \\ Zuzana Homolová ${ }^{4}$
}

\author{
${ }^{1}$ Department of Veterinary Sciences, Faculty of Agrobiology, Food and Natural Resources, Czech University \\ of Life Sciences Prague, Kamýcká 129, CZ-165 00 Praha, Czech Republic \\ ${ }^{2}$ Institute of Forest Ecology SAS, L. Štúra 2, SK-960 53 Zvolen, Slovakia \\ ${ }^{3}$ Catholic University in Ružomberok, Hrabovská cesta 1, SK-034 01 Ružomberok, Slovakia \\ ${ }^{4}$ Research Station of the Tatra National Park, State Forests, SK-059 60 Tatranská Lomnica, Slovakia
}

\begin{abstract}
HlôšKa, L., Saniga, M., Chovancová, G., Chovancová, B., Homolová, Z., 2022. Temporal and spatial changes in small mammal communities in a disturbed mountain forest. Folia Oecologica, 49 (1): 9-22.

In 2005-2016, we investigated a secondary succession of small mammal communities in forest ecosystems in High Tatras (Slovakia) disturbed by windstorm and fire. This long-term ecological study confirmed the occurrence of significant temporal and spatial changes in species composition and number of dominant small mammal species. A comparison between disturbed and undisturbed plots indicated notable differences in species richness and abundance. The gradations of dominant small mammal species in disturbed habitats were asynchronous and showed a wider range of amplitude than in the undisturbed plots. An analysis of the temporal and spatial changes in the structure of small mammal communities in relation to selected environmental gradients confirmed the statistically significant effect of secondary succession on species composition, abundance, and exchange in forest ecosystems in the High Tatra Mountains following a disturbance.
\end{abstract}

\section{Keywords}

disturbance, habitat selection, plant succession, small mammals

\section{Introduction}

In recent decades, forest disturbance regimes have intensified in many parts of the world (CHAPIN et al., 2000; SCHELHAAS et al., 2003; BALSHI et al., 2007; GARDINER et al., 2010). Large wildfires in western North America, for instance, occurred nearly four times as often in 1987-2003 as in 1970-1986 (WesterLING et al., 2006), and damage from bark beetles reached unprecedented levels (MEDDENS et al., 2012). A similar trend is evident in wildfires, windthrows and bark beetles in Europe (ScHELHAAs et al., 2003; SeIDL et al., 2014). This trend is likely to continue in the future, as a result of the changes in climate that are expected to unfold over the coming decades (SEIDL et al., 2011; Li et al., 2013; Reichstein et al., 2013; TemPerLi et al., 2013; SEIDL et al., 2014). In many areas, changes in the disturbance regime (i.e., in the distinctive type, size, severity and frequency of disturbances over extended spatio-temporal scales) are expected to be among the most severe climate change impacts on forest ecosystems (Lindner et al., 2010; TURNER, 2010). In general, disturbances are important natural drivers of forest ecosystem dynamics (FrANKLIN et al., 2002) and strongly modulate the structure and functioning of forest ecosystems (TURNER, 2010).

\footnotetext{
*Corresponding author: e-mail: ladislav.hloska@gmail.com 
Intensive storms and whirlwinds are becoming more frequent in Central Europe and their negative impact on forest ecosystems and the carbon balance is growing. Estimates suggest up to a $2 \%$ decrease in forest carbon stocks per year (GARDINER et al., 2010). These authors consider the increasing temperature and precipitation to be critical factors damaging forest ecosystems. In general, global warming and weather extremes induce geographic changes in the species composition and structure of forest communities (e.g. Chapin et al., 2000). Based on the results of a comprehensive analysis of published data on disturbed forest ecosystems in Europe, ShEalHaAs et. al (2003) stated that for the period 1950-2000, storms accounted for $53 \%, 16 \%$ for forest fires, $3 \%$ for snow and $5 \%$ for other abiotic factors. According to these authors, biotic factors accounted for $15 \%$ of forest damage and $7 \%$ of disturbances were caused by the combined action of several factors.

Several studies have addressed the issue of the effect of natural and anthropogenic disturbances on the subsequent succession of small mammal communities in the forest ecosystems of Scandinavia, Eastern and Central Europe. In Scandinavia (southeastern Norway), changes in the structure and population dynamics of small mammals induced by anthropogenic disturbances in the country were addressed by a study by PANZACCHI et al. (2010). The analysis of the data obtained by them confirmed the significant influence of selected vegetation variables on the patterns of species groups of small mammals. BALČIAUSKAS et al. (2017) studied how early forest succession affects species composition, diversity, abundance and biomass of small mammals. They compared small mammal communities in habitats at different successional stages. They recorded the highest species diversity in the meadow community, the lower in the young forest and the lowest in the adult forest stage, while the terminal habitat was the most monodominant.

In the conditions of Central Europe, several authors have investigated the responses of small mammals to natural and anthropogenic disturbances, succession and productivity of forest ecosystems (wind disaster, fires, logging, vegetation succession, climate change, the impact of snow cover, etc.). E.g. in forest communities in the territory of north-eastern Poland NiEDZIALKOwSKA et al. (2010), in the Czech Republic ZÁRYBNická et al. (2017) and in Slovakia (High Tatras) HLôšKA et al. (2016). Quantitative and qualitative meta-analysis of available data on the responses of small mammal communities to different disturbance regimes in the temporal and boreal forests of Europe was performed by BoGDZIEWICZ and ZWOLAK (2014). The meta-analysis of the data performed by these authors confirmed the positive influence of the initial and middle successive stages of the forest on the abundance of small mammals. In general, the anthropogenic destruction of natural habitats conditions the distribution of invasive and generalist species of small mammals, which become dominant in the disturbed country. On the contrary, spontaneous succession and regeneration of forest ecosystems, leading to natural habitats, conditions the occurrence and survival of specialized taxa, demanding greater temporal and spatial heterogeneity of habitats and resources (eg UMETSU and PARDINI, 2007).

Small mammal communities found in Tatra mountains are spatially diversified (HANZÁK and RosickÝ, 1949; KowALSKI, 1957; 1960; KratochVÍl, 1968; 1970; Kratochvíl and Pelikán, 1955; Pelikán, 1955; ŠTollmanN and Dudich, 1985) and local species structure depens on productivity, age, forest type (KRATOCHVÍl and GAISLER, 1967). But is not clear how these communities change following disturbances like fires or windthrows, and during following successional stages, after the disturbance.

In the recent past, forest ecosystems in the Tatra National Park (TANAP) have been exposed to natural disturbances: in November 2004, this area saw a windstorm and a fire in 2005. As a result, large areas impacted by wind and fire of more than $120 \mathrm{~km}^{2}$ occurred in the montane and supramontane zones. This area and its windthrows and windbreaks serve as a valuable model area where we could perform long-term observations of postdisturbance changes in the populations and communities of small mammals in natural conditions. Secondary succession and related increases in habitat complexity have provided us with unique background conditions to study the responses of particular small mammal species to changes in selected habitat characteristics that are unique for disturbed mountain forests in Central Europe.

In this study, we implemented a long-term ecological study of post-disturbance succession changes in small mammal communities in forest ecosystems in the High Tatra Mountains. We identified little-known predictors of continuous temporal and spatial changes in the distribution and structure of small mammal communities following extensive disturbance in forest ecosystems.

Based on previous study we hypothesize that species preferring open and semi-open habitats will increase in number after the disturbance but their abundance will decrease in number with the advancement of forest succession. Based on the analysis of data from long-term research conducted in the period 2005-2016, we tried to verify hypotheses (i) about species-specific responses of mammals to increasing habitat heterogeneity during secondary succession of vegetation cover after disturbance and (ii) different effects of selected environmental variables (succession changes species diversity of plant communities, vegetation cover) and abundance and species richness of small mammals in disturbed and nondisturbed forest communities.

\section{Materials and methods}

\section{Study site}

The study was conducted in the north part of Slovakia (Central Europe), in the territory of the Tatra National Park (High Tatras). The study area was located from 925 to $1,260 \mathrm{~m}$ above sea level $\left(49^{\circ} 08^{\prime} 17^{\prime} \mathrm{N}, 20^{\circ} 13^{\prime} 05^{\prime \prime} \mathrm{E}\right)$.

The research was carried out in the area of the High 
Tatra Range in following six localities and seven research plots (Fig. 1):

\section{Disturbed areas - forest ecosystems after wind calamity in 2004:}

"OVL" (Oliverov vodný les) and Tatranská Lomnica, forest stands affected by wind calamity (2004) and with water measures applied. Successional changes in species richness and cover after disturbance in 2004 were identical as in the CVL area. Destruction of the tree layer, reduction of the shrub layer, secondary succession of the herbaceous layer in the sparsely stocked stand. Forestry management: removal of wood, artificial regeneration, mowing around seedlings and reduction of pioneer trees. The variation ranges of cover (p) and number of plant species (NPS) changed during the years 2005-2016 as follows: $\mathrm{p} \mathrm{E}_{3}$ (tree layer) $=3-5 \%$, NPS $\mathrm{E}_{3}=0-3 ; \mathrm{p} \mathrm{E}_{2}$ (shrub layer) $=12$ $32 \%$, NPS $\mathrm{E}_{2}=1-6 ; \mathrm{p}_{1}$ (herbaceous layer) $=20-86 \%$, NPS $\mathrm{E}_{1}=5-11$.

"NEX" (Jamy), forest stands affected by wind calamity in 2004, no management intervention (no salvaging of windthrown and broken trees, no reforestation) Spontaneous secondary succession of forest phytocenoses in ecological niches released after disturbance. Before the wind disaster, there was a forest community belonging to the group of forest types Lariceto-Piceetum. After disturbance in the years 2005-2016, cover and number of plant species in individual stages varied in the following ranges: $\mathrm{p}_{3}=$ $0-20 \%$, NPS $\mathrm{E}_{3}=1-5 ; \mathrm{p} \mathrm{E}_{2}=4-20 \%$, NPS $\mathrm{E}_{2}=1-5 ; \mathrm{p} \mathrm{E}_{1}=$ $68-45 \%$, NPS E $\mathrm{E}_{1}=8-14$.

"CVL" (Čierny vodný les) and Nový Smokovec, forest stands affected by wind calamity (2004) and with waterholding measures applied. The physiognomy of the plant community was similar to the phytocenoses of the initial stages of secondary succession in the EXT and FIRE areas one year after disturbance (2005). Destruction of the tree layer, reduction of the shrub layer and secondary succession of the herbaceous layer in the sparsely stocked stand. Forestry management: removal of timber, artificial regeneration. Spontaneous development of a shrub layer (pioneer trees). The variation range of cover and number of plant species in the years 2005-2016 changed as follows: $\mathrm{p} \mathrm{E}_{3}=1-5 \%, \mathrm{NPS}_{3}=0-3 ; \mathrm{p} \mathrm{E}_{2}=3-12 \%, \mathrm{NPS} \mathrm{E}_{2}=1-6$; $\mathrm{p} \mathrm{E}_{1}=20-88 \%$, NPS $\mathrm{E}_{1}=5-20$.

"EXT" (Danielov dom), forest stands affected by wind calamity in 2004, treated with applying common forestry measures (wood mass removed, plot partly reforested). Destruction of the tree layer, reduction of the shrub layer and secondary succession of the herbaceous layer in the sparsely stocked stand. Forestry management: removal of wood, artificial regeneration, mowing around seedlings and reduction of pioneer trees. The values of cover and species richness of vegetation layers in the years 20052016 oscillated in the ranges: $\mathrm{p} \mathrm{E}_{3}=3-5 \%$, NPS $\mathrm{E}_{3}=1-2$; $\mathrm{p}_{2}=3-10 \%$, NPS $\mathrm{E}_{2}=3-4 ; \mathrm{p} \mathrm{E}_{1}=18-45 \%$, NPS $\mathrm{E}_{1}=$ $12-15$.

Disturbed areas - forest ecosystems after wind calamity in 2004 and forest fire in 2005:

"FIR1A" and "FIR3A" (Tatranské Zruby), plots in forest stands affected by wind calamity (2004) and later by fire (2005). Total destruction of vegetation (fire) and secondary succession of the herbaceous layer in the sparsely stocked stand. Forestry management: removal of wood, artificial regeneration, mowing around seedlings and reduction of pioneer trees. In the time interval 20052016, the percentage of cover and plant species richness of individual levels changed as follows: $\mathrm{p}_{3}=0-5 \%$, NPS $\mathrm{E}_{3}$ $=0-3 ; \mathrm{p} \mathrm{E}_{2}=3-32 \%$, NPS $\mathrm{E}_{2}=1-6 ; \mathrm{p} \mathrm{E}_{1}=2-80 \%$, NPS $\mathrm{E}_{1}=5-18$.

\section{Undisturbed areas - forest ecosystems without distur- bances:}

"REF" (Smrekovec), intact stands, the reference (control) plot. Species of undisturbed forest phytocenosis (group of forest types Lariceto-Piceetum). Adult forest stand aged

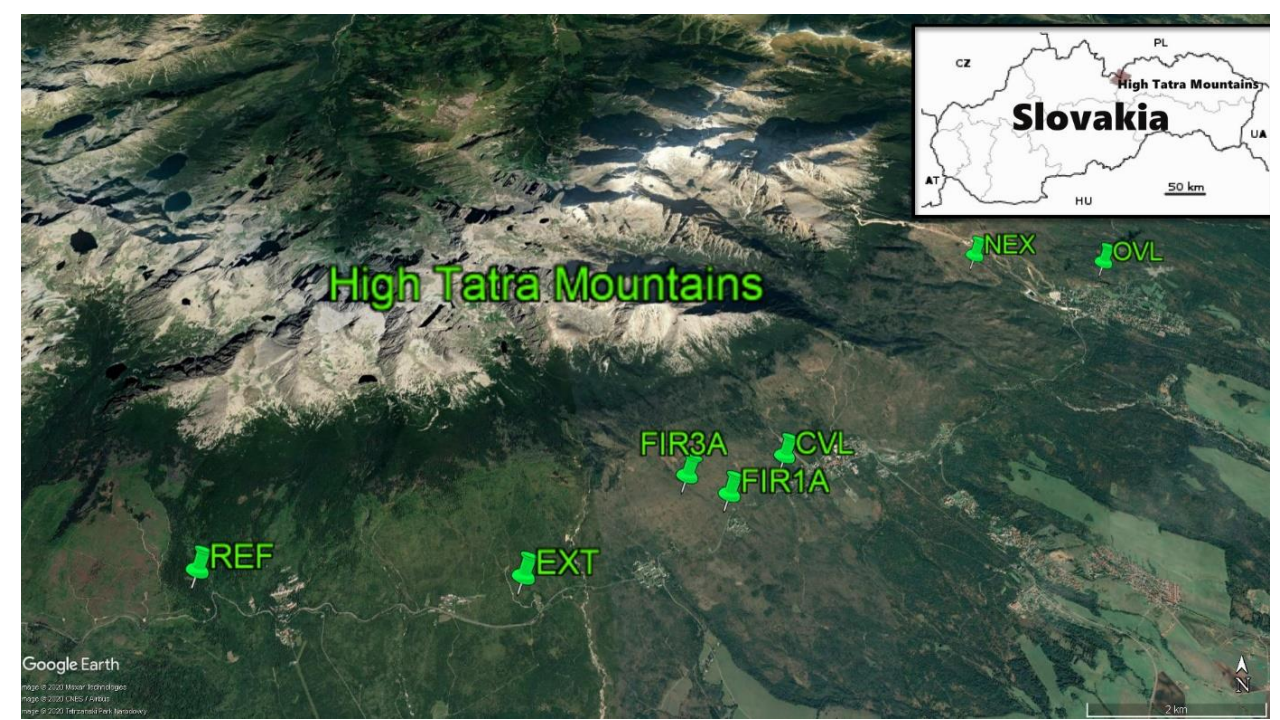

Fig. 1. Spatial distribution of permanent research areas in the studied area. The description of the permanent study plots and their classification according to the disturbance regime are given below. 
80-100 years. Forest phytocenosis differs significantly from other disturbed areas by both spatial structure and species composition. The values of cover and species richness of vegetation layers in the years 2005-2016 oscillated in the ranges: $\mathrm{p} \mathrm{E}_{3}=49-63 \%$, NPS $\mathrm{E}_{3}=1-2 ; \mathrm{p}$ $\mathrm{E}_{2}=4-20 \%, \mathrm{NPS}_{2}=2 ; \mathrm{p} \mathrm{E}_{1}=68-55 \%, \mathrm{NPS}_{1}=15-16$.

\section{Small mammal sampling}

We applied the capture-mark-recapture method to sample small mammals. On each of the seven research areas there was focused and marked in the field study quadrat $75 \times 75 \mathrm{~m}$ and it was divided into a grid of $15 \times 15 \mathrm{~m}$ squares. In the angles of this grid, trapping points (36 per quadrat) were localized and visibly marked to ensure that every recapture, even after a long period of time, would be performed at the same place in the field. For trapping, 36 Sherman live traps were set for 4 days and 3 nights in this area. The catch effort for the whole research period (2005-2016) corresponds to the value of 2,532 nights and traps. We captured small mammals in the field on all experimental quadrates $(n=7)$ simultaneously or with a three-day time shift, with one capture series lasting 1 week. In this way we eliminated the time variability of the obtained samples. In the given year, we repeated the catches twice (in the spring and autumn period). During the research period 2005-2016 we realized 24 such capture series in the surveyed area. We baited the traps with a mixture of walnuts, canned sardines, oat flakes, and fly pupae of the order Diptera. We countered traps at least twice a day. We determined the species, age and sex of the captured individuals, and we weighed them using the PESOLA spring scale, with an accuracy of $0.5 \mathrm{~g}$. Finally, we marked them with ear tags that featured a unique numeric code. Marked individuals were released at the trapping point. At every study plot we estimated the relative number of small mammals as the minimum number known alive (BEAUvaIs and BUSKIRK, 1999). MNA is defined as the number individuals caught in a capture session, plus those that were not caught at that time but were caught both previously and subsequently (KreBs, 1966).

\section{Vegetation sampling}

Vegetation sampling was performed repeatedly during the growing season (May to July) at the same points, located in the angles of the internal mesh in the permanent research plots (36 points per quadrat). It was carried out in circles with a radius of $2 \mathrm{~m}$ and centres identical with the places where live traps were set during trapping. On each of the circular sampling plots, a complete species inventory of plants, their heights and the estimated coverage on individual vegetation layers was performed. A repeated vegetation sampling was performed after the minimum interval of 1 year (a total of 7 images at 252 circular imaging points during the research period 2005 2016) to give us a more complete view of temporal and spatial changes in the structure of plant communities for particular stages of secondary succession in forest communities impacted by a disturbance.

\section{Statistical analyses}

To eliminate pseudoreplication and the effects of repeated catches on behavioural responses (SÁNCHEZ-GonZÁLES et al., 2017), habit selection, or reactions of already captured individuals on studied habitat characteristics, we only used data on $1 \times$ captured individuals in the statistical analyses.

To test for differences in the abundance and species richness of small mammals between disturbed and nondisturbed experimental plots during the 2006-2016 research period, we used a generalized linear models (GLM). We included 1,629 data records with values of selected quantitative and categorical variables in the analyzes. The variable explained was either the abundance of small mammals, then we used GLM with Poisson error distribution, or the species richness of small mammals, and in this case we applied GLM with negative binomial distribution. Predictors in these models were time data (years) in relation to the degree and type of habitat disturbance.

We applied a linear discriminant analysis (LDA) to determine which vegetation variables had effects on the species composition or spatial structure of habitats with different types and intensities of disturbance. We included objects ( 7 areas) coded according to the intensity of disturbances on the given area in the prediction model $(\mathrm{k}$ $=3 ; \mathbf{1}=$ disturbed forest ecosystems after wind calamity in 2004; $\mathbf{2}$ = forest ecosystems without disturbances; $\mathbf{3}=$ disturbed forest ecosystems after wind calamity in 2004 and forest fire in 2005). We investigated the influence of 6 discriminators - quantitative data on vegetation cover (3 discriminators) and data on species diversity of plant communities (3 discriminators) - measured in individual years (vegetation seasons) of the research period 2005-2016 ( $\mathrm{n}=1,512 ; 84$ measurements). To assess the statistical significance of selected discriminators for the classification of areas into disturbance classes, we used Wilk's criterion $\lambda$ and F-test (e.g. ZuUR et al., 2007). When classifying objects, we used canonical correlation analysis (e.g. Meloun et al., 2017).

Statistical analyses were performed using NCSS 9.0.22 statistical software (NCSS 9 Statistical Software 2013). Furthermore, in the environment of the CANOCO 5.12 program (ك̌MILAUER and LEPŠ, 2014) we tested the spatiotemporal changes in species composition, distribution and abundance of small mammals induced by secondary succession of plant communities after disturbance of forest habitats (whirlwind, forest fire). In the test model, the species variables represented by the relative abundance of each small mammal species were presented as the response variables. The explanatory variables in this model were successive changes of species composition and horizontal structure of vegetation (cover of vegetation layers). We used the direct gradient analysis (RDA) method to test the statistical significance of the impact of the abovementioned explanatory variables on changes in the spatiotemporal structure of small mammalian communities. 
The responses of selected species of small mammals to successive changes in the structure of the vegetation profile were tested using regression models (in the specific case we used generalized linear models - GLM) (ك̌MILAUER and LEPŠ, 2014).

\section{Results}

\section{Small mammal community structure}

In 2005-2016, we trapped and measured 1,305 individuals from 14 small mammal species (Table 1).

Throughout this whole research period, five species typical for all succession stages and areas occurred regularly both on disturbed (OVL, NEX, CVL, FIR1A, FIR3A, EXT) and undisturbed plots (REF); Clethrionomys glareolus, Sorex araneus, Apodemus flavicollis, Microtus agrestis and Sorex minutus. The species richness of small mammals in the particular study plots ranged from five to eight species. The lowest species richness (five species) was recorded in the reference plot in adult forest stands (REF), and the highest (eight species) was measured in the disturbed areas in late stages of secondary succession (OVL, CVL).

\section{Temporal changes in community structure}

The early stages of secondary succession were characterized by an increase in abundance of the small mammal communities in the first 4 years after disturbance, culminating in 2009 ( $\mathrm{n}=249$ individuals). In late succession stages (2010-2016), the abundance of small mammals decreased, reaching minimum values in 2014 (14 individuals). The fluctuation curve expressing the abundance of small mammal communities in disturbed areas showed wide amplitude, while it was narrow in the undisturbed habitats (Fig. 2). The differences between the communities in the disturbed and undisturbed areas were significant (GLM with Negative binomial: $\chi_{22}^{2}=35.511$; $P=0.034)$. The early succession stages in disturbed habitats showed greater variation in species richness than the undisturbed ones, averaging higher in the first 9 years following the disturbance (GLM with Poisson error distribution: $\left.\chi_{21}^{2}=72.658 ; P<0.001\right)$. In the late succession stages, the species richness of small mammals declined until it stabilized at the level reported in communities living in undisturbed habitats (Fig. 3).

The temporal differences in species composition of small mammal communities are presented in the dendrogram in Fig. 4. The communities of small mammals in disturbed areas showed the highest similarity in the initial stages of secondary succession (in 2005-2010). These communities had a specific species composition, which differed significantly from the communities in the middle stages of development (2008-2013). We recorded the highest degree of dissimilarity in the later stages of succession (2014-2016). The communities of early succession stages just after disturbance formed 8 species of small mammals (Fig. 5). Species typical only for early succession stages were 2 (in parentheses after the binary name of the species we indicate the frequency of its occurrence): Apodemus sylvaticus (33.3\%) and Neomys anomalus (16.7\%). In the communities of the initial successive stage, the following species also occurred: C. glareolus $(100.0 \%)$, M. agrestis (100.0\%), S. araneus (83.3\%), A. flavicollis (83.3\%),

Table 1. Number and dominance of small mammals on particular study plots in 2005-2016

\begin{tabular}{|c|c|c|c|c|c|c|c|}
\hline Species / Study plot & $\begin{array}{l}\text { OVL } \\
(\%)\end{array}$ & $\begin{array}{l}\text { NEX } \\
(\%)\end{array}$ & $\begin{array}{l}\text { CVL } \\
(\%)\end{array}$ & $\begin{array}{l}\text { FIR1A } \\
(\%)\end{array}$ & $\begin{array}{l}\text { FIR3A } \\
(\%)\end{array}$ & $\begin{array}{l}\text { EXT } \\
(0 \%)\end{array}$ & $\begin{array}{l}\text { REF } \\
(0 \%)\end{array}$ \\
\hline Apodemus agrarius & 0.0 & 2.7 & 0.0 & 0.0 & 0.0 & 0.0 & 0.0 \\
\hline Apodemus flavicollis & 10.6 & 7.1 & 17.6 & 25.9 & 13.8 & 10.8 & 8.7 \\
\hline Apodemus sylvaticus & 0.0 & 0.0 & 0.0 & 0.9 & 0.0 & 0.5 & 0.0 \\
\hline Arvicola amphibius & 0.9 & 0.0 & 0.5 & 0.0 & 0.0 & 0.0 & 0.0 \\
\hline Clethrionomys glareolus & 46.1 & 71.2 & 47.2 & 31.9 & 58.1 & 41.1 & 84.7 \\
\hline Micromys minutus & 0.0 & 1.1 & 0.0 & 0.0 & 0.6 & 0.0 & 0.0 \\
\hline Microtus agrestis & 8.8 & 2.7 & 7.3 & 8.3 & 8.8 & 11.9 & 0.7 \\
\hline Microtus arvalis & 0.0 & 0.0 & 0.5 & 0.0 & 1.3 & 0.0 & 0.0 \\
\hline Muscardinus avellanarius & 0.0 & 0.0 & 0.0 & 2.3 & 0.0 & 0.0 & 0.0 \\
\hline Neomys anomalus & 0.5 & 0.0 & 0.0 & 0.0 & 0.0 & 0.0 & 0.0 \\
\hline Neomys fodiens & 1.4 & 0.0 & 2.1 & 0.0 & 0.0 & 0.0 & 0.0 \\
\hline Sicista betulina & 0.0 & 0.0 & 0.0 & 0.0 & 0.0 & 0.5 & 0.0 \\
\hline Sorex araneus & 28.6 & 13.0 & 20.7 & 29.2 & 15.0 & 31.9 & 5.3 \\
\hline Sorex minutus & 3.2 & 2.2 & 4.2 & 1.4 & 2.5 & 3.2 & 0.7 \\
\hline Number of individuals (n) & 217 & 184 & 193 & 216 & 160 & 185 & 150 \\
\hline Number of species & 8 & 7 & 8 & 7 & 7 & 7 & 5 \\
\hline
\end{tabular}

OVL: NEX, CVL, FIR1A, FIR3A, EXT, disturbed plots; REF: reference plot, undisturbed. 


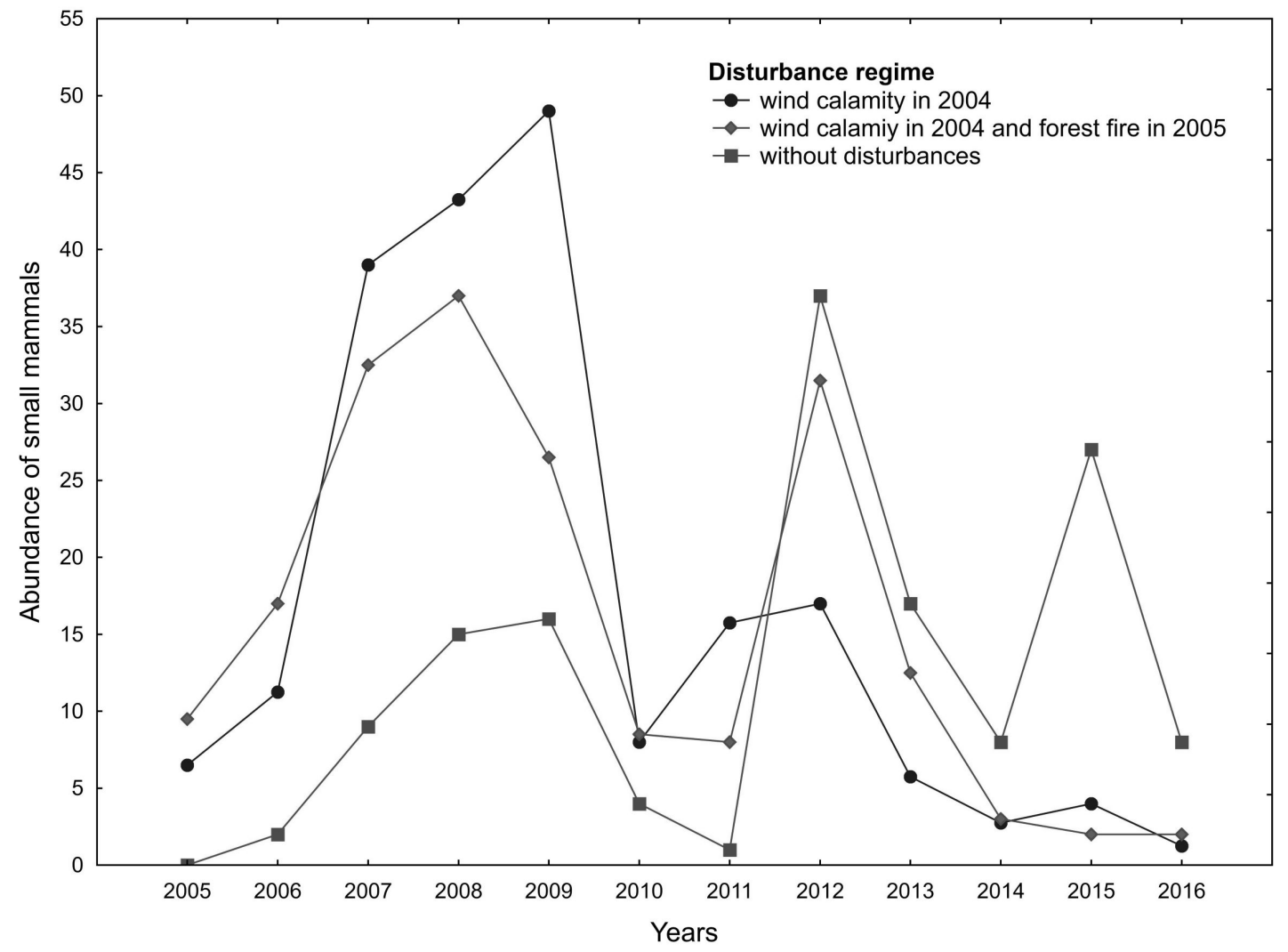

Fig. 2. Temporal changes in abundance of small mammals in relation to disturbance in forest ecosystems, $\mathrm{n}=1,629$.

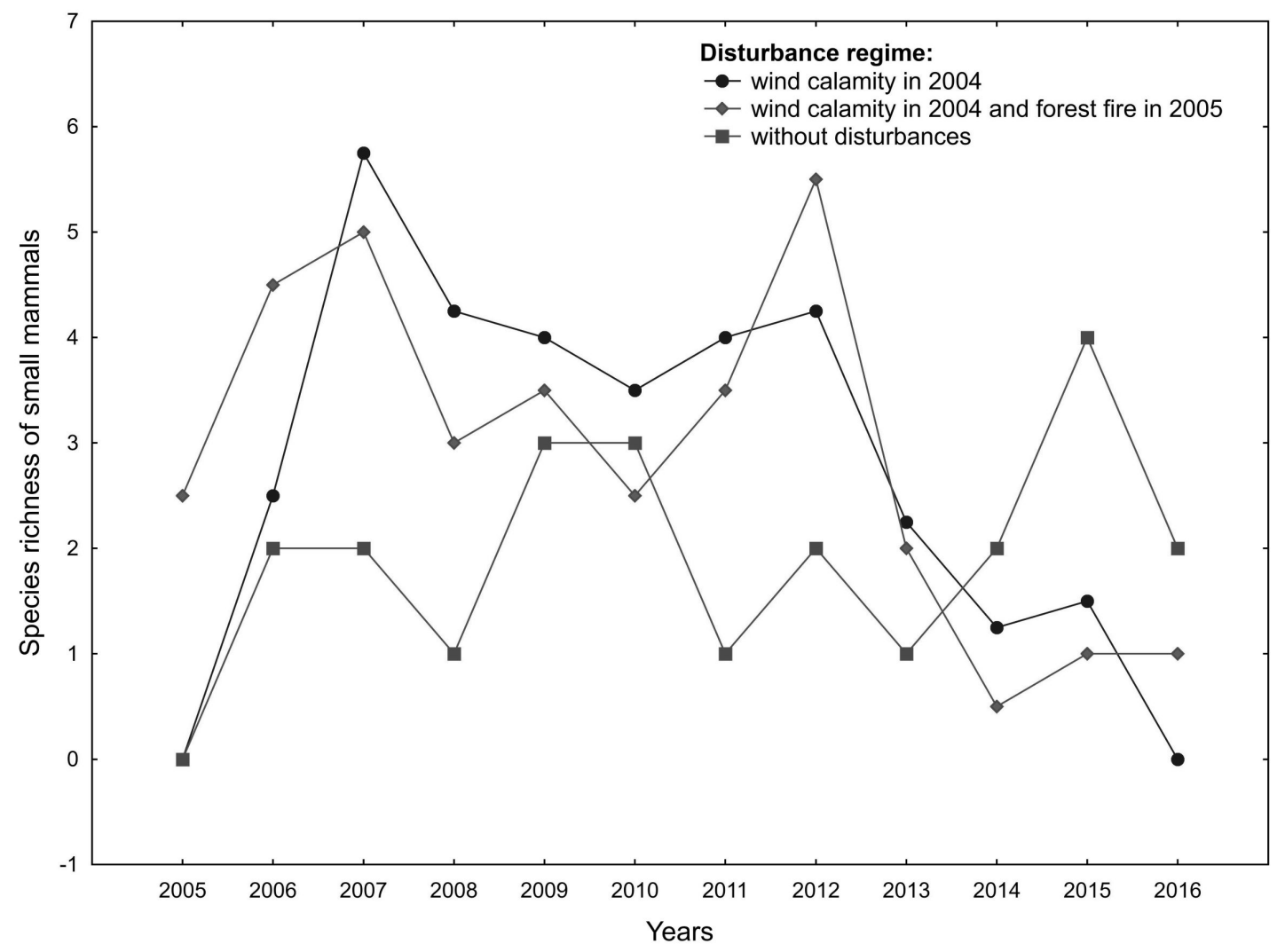

Fig. 3. Temporal changes in species richness of small mammals in relation to disturbance in forest ecosystems. 
S. minutus (33.2\%) and Neomys fodiens (16.7\%). In the middle phase of post-disturbance development (20082013), we recorded an increase in species richness in small mammal communities (from 8 to 11 species). Specific for this succession stage were the following species; Muscardinus avellanarius $(50.0 \%)$, Microtus arvalis (33.3\%), Sicista betulina (16.7\%) and Arvicola amphibius $(16.7 \%)$ In the later successive stage (2014-2016) there was a decrease in species richness (from 11 to 6 species). Only in this succession phase we recorded the occurrence of Apodemus agrarius (33.3\%). The frequency of occurrence of other species in samples from the given time interval was as follows: $S$. araneus (33.3\%), S. minutus (33.3\%), $A$. flavicollis (19.0\%), M. minutus (16.7\%) and C. glareolus (14.0\%).

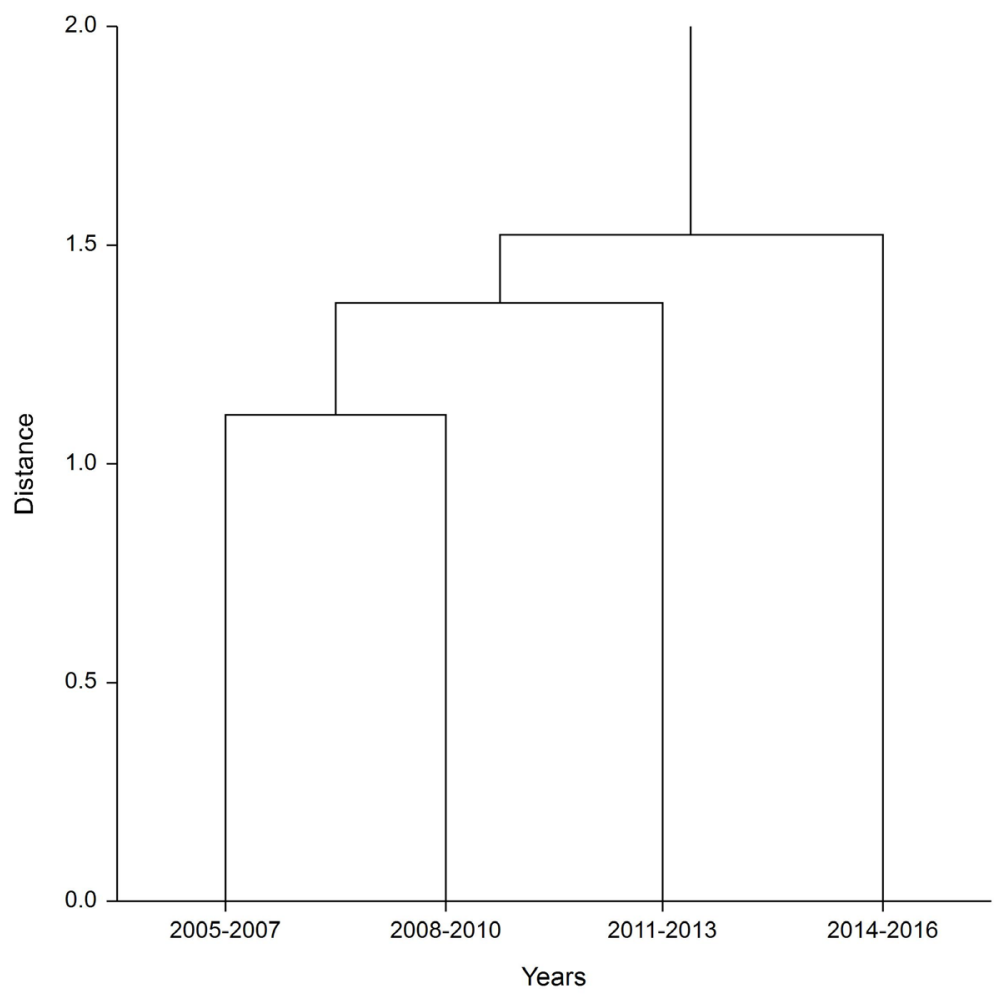

Fig. 4. Dendrogram showing similarities of temporal changes in composition of small mammal species following a disturbance in forest ecosystems during the study period 2005-2016.

\begin{tabular}{|c|c|c|c|c|}
\hline \multirow{2}{*}{\multicolumn{5}{|c|}{ Apodemus sylvaticus }} \\
\hline & & & & \\
\hline \multicolumn{5}{|l|}{ Neomys anomalus } \\
\hline \multicolumn{5}{|l|}{ Microtus agrestis } \\
\hline \multicolumn{5}{|l|}{ Neomys fodiens } \\
\hline \multirow{2}{*}{\multicolumn{5}{|c|}{ Apodemus flavicollis }} \\
\hline & & & & \\
\hline \multicolumn{5}{|l|}{$\begin{array}{r}\text { Sorex araneus } \\
\text { Sons }\end{array}$} \\
\hline \multicolumn{5}{|l|}{ Sorex minutus } \\
\hline \multicolumn{5}{|l|}{ Arvicola amphibius } \\
\hline \multicolumn{5}{|l|}{ Microtus arvalis } \\
\hline \multicolumn{5}{|l|}{$\begin{array}{r}\text { Muscardinus avellanarius } \\
\text { Sicista betulina }\end{array}$} \\
\hline Sicista betulina & & & & \\
\hline \multirow{2}{*}{\multicolumn{5}{|c|}{$\begin{array}{l}\text { Micromys minutus } \\
\text { Apodemus agrarius }\end{array}$}} \\
\hline & & & & \\
\hline & $\begin{array}{c}\text { Initial phase } \\
\text { increasing coverage } \\
\text { of the herbaceous } \\
\text { layer }\end{array}$ & $\begin{array}{r}\text { Inter } \\
\text { increasing co }\end{array}$ & $\begin{array}{l}\text { hase } \\
\text { fgrasses and }\end{array}$ & $\begin{array}{l}\text { Advanced phase } \\
\text { increasing height } \\
\text { and coverage trees }\end{array}$ \\
\hline
\end{tabular}

Fig. 5. Block diagram showing the occurrence of individual species of small mammals in different successive phases of disturbed habitats $(2005-2016, \mathrm{n}=1,171)$. Grey boxes = presence; empty fields = absence of the given species of small mammal in the succession series. 


\section{Impact of plant secondary succession}

We used linear discriminant analysis (LDA) to test the influence of the type and intensity of disturbance on the species composition and dynamics of successive changes in vegetation. The objects (dependent variables) of the analysis were research areas $(n=7)$ classified into one of 3 classes of disturbance regime with different intensity of disturbances; 1 - disturbed forest ecosystems after wind calamity in 2004 (OVL, NEX, CVL and EXT); 2 - forest ecosystems without disturbances (REF); 3 - disturbed forest ecosystems after wind calamity in 2004 and forest fire in 2005 (FIR1A and FIR3A). The independent variables (discriminators) used to classify objects in our discriminant model were quantitative data on the cover and species richness of individual vegetation layers in individual years of research (6 discriminators; $\mathrm{n}=1,512)$. The effect of all 6 discriminators selected for classifying areas into classes with different disturbance regimes was significant (Table 2). The highest discriminant force - expressed by the value of Wilk's criterion $\lambda$ - was characterized by 3 discriminators (in descending order): $\mathbf{p}$ $\mathbf{E}_{\mathbf{3}}$ (tree layer coverage), NPS $\mathbf{E}_{\mathbf{3}}$ (number of species in the tree layer and $\mathbf{p} \mathbf{E}_{\mathbf{1}}$ (herbaceous layer coverage).

Areas with disturbance mode $\mathbf{1}$ in comparison with the reference area without disturbance (disturbance mode 2) were characterized by higher average cover of the herbaceous layer ( $\mathbf{p} \mathbf{E}_{1}$ ) and higher species richness of the shrub layer (NPS $\mathbf{E}_{2}$ ), but lower average values of cover of the shrub layer $\left(\mathbf{p} \mathbf{E}_{\mathbf{1}}\right)$ and tree layer $\left(\mathbf{p} \mathbf{E}_{\mathbf{3}}\right.$ ), as well as lower average herb species richness (NPS $\mathbf{E}_{\mathbf{1}}$ ) and tree layer (NPS $\mathbf{E}_{3}$ ). Areas with disturbance regime $\mathbf{3}$ with higher intensity and extent of disturbances had, with the exception of higher cover of shrub layer $\left(\mathbf{p} \mathbf{E}_{2}\right)$, lower values of species richness of vegetation layers (NPS $\mathbf{E}_{1}$ and NPS $\mathbf{E}_{3}$ ), as well as cover of herbaceous ( $\left.\mathbf{p} \mathbf{E}_{1}\right)$ and tree layer $\left(\mathbf{p} \mathbf{E}_{3}\right)$ than the reference area and areas with disturbance mode 2 (Table 2).

The graph of the linear discrimination score (Fig. 6) discriminates between the reference area (REF) without disturbances and disturbed areas with disturbance categories 1 and 3. High tree layer cover on the reference area, and at the same time higher succession age of the forest community disturbed study plots. Disturbed areas were characterized by higher herb cover (disturbance mode 1) or shrub layer (dist. mode 3), higher species diversity of the shrub layer and also lower species richness of the herbaceous and tree layer of the vegetation profile. Areas with initial and young successive stages of plant communities are concentrated in the projection space of the graph at the bottom left as overlapping clusters, successively more progressively forming a separate cluster of objects at the top right.

The results of the canonical correlation analysis (Table 3 ) showed that the $1^{\text {st }}$ distribution function (successive stage of the habitat) correlated most strongly with the cover of the tree layer $\left(\mathbf{p} \mathbf{E}_{3} ; \beta=0.99\right)$, which grew in direct proportion to the age of the trees. The $2^{\text {nd }}$ distribution function (cover and species richness of vegetation at the site) correlated most closely with the cover of herbaceous $\left(\mathbf{p} \mathbf{E}_{1} ; \beta=0.52\right)$ and shrub layer (p E2; $\beta=-0.56$ ) and weaker with the species richness of shrub layer (NPS E $\mathbf{E}_{2}$; $\beta=0.22$ ).

Changes in overall vegetation coverage led to speciesspecific responses in sample populations of dominant small mammals (Constrained RDA: pseudo- $F=1.90$; $P=0.008$; Fig. 7). In habitats after disturbance, we recorded the highest growth rate of abundance in 2 ubiquitous rodent species (C. glareolus and A. flavicollis), which were dominant in disturbed communities throughout the research period (2005-2016). During the secondary succession of vegetation, $C$. glareolus preferred habitats with increasing tree cover $\left(\mathbf{p} \mathbf{E}_{\mathbf{3}}\right)$ and moss cover (p E $\mathbf{E}_{\mathbf{0}}$ ), while A. flavicollis species positively increased its abundance along the gradients of shrub layer species (NPS $\mathbf{E}_{2}$ ) and cover herbaceous layer $\left(\mathbf{p} \mathbf{E}_{\mathbf{1}}\right)$. The abundance of $S$. araneus positively correlated with the gradient of increasing species richness of the tree layer (NPS $\mathbf{E}_{3}$ ), less so with the gradient of herbaceous cover (NPS $\mathbf{E}_{\mathbf{1}}$ ). S. minutus preferred habitats where during the succession

Table 2. Output of LDA analysis. Discriminators (coverage and species richness on vegetation layers) with a significant impact on the succession in forest phytocoenosis and different disturbance regime

\begin{tabular}{|c|c|c|c|c|c|c|}
\hline \multirow{2}{*}{ Discriminators } & \multicolumn{3}{|c|}{ Disturbance regime } & \multirow{2}{*}{$\begin{array}{l}\text { Wilks' } \\
\text { Lambda }\end{array}$} & \multirow{2}{*}{ F-Value } & \multirow{2}{*}{ P-Prob } \\
\hline & $1(\mathrm{x})$ & $2(x)$ & $3(\mathrm{x})$ & & & \\
\hline$\overline{p E_{3}}$ & 1.16 & 43.14 & 0.14 & 0.27 & 740.74 & $<0.001$ \\
\hline $\mathrm{p} \mathrm{E}_{2}$ & 6.39 & 2.14 & 40.09 & 0.67 & 132.35 & $<0.001$ \\
\hline $\mathrm{p} \mathrm{E}_{1}$ & 86.36 & 68.14 & 39.82 & 0.60 & 176.97 & $<0.001$ \\
\hline $\mathrm{NPS} \mathrm{E}_{3}$ & 0.11 & 1.14 & 0.00 & 0.44 & 338.57 & $<0.001$ \\
\hline NPS E 2 & 0.67 & 0.37 & 0.19 & 0.88 & 12.55 & $<0.001$ \\
\hline NPS E $_{1}$ & 13.51 & 17.26 & 10.90 & 0.89 & 11.20 & $<0.001$ \\
\hline
\end{tabular}

Discriminators: $\mathrm{p}_{3}$, tree layer coverage; $\mathrm{p}_{2}$, shrub layer coverage; $\mathrm{p} \mathrm{E}_{1}$, herbaceous layer coverage; NPS $\mathrm{E}_{3}$, number of species in the tree layer; NPS $E_{2}$, number of species in the shrub layer; NPS $E_{1}$, number of species in the herbaceous layer. Objects (areas) divided into classes according to a different disturbance mode: 1 - disturbed forest ecosystems after wind calamity in 2004 (OVL, NEX, CVL and EXT); 2 - forest ecosystems without disturbances (REF); 3 - disturbed forest ecosystems after wind calamity in 2004 and forest fire in 2005 (FIR1A and FIR3A); $x=$ sampling average. 


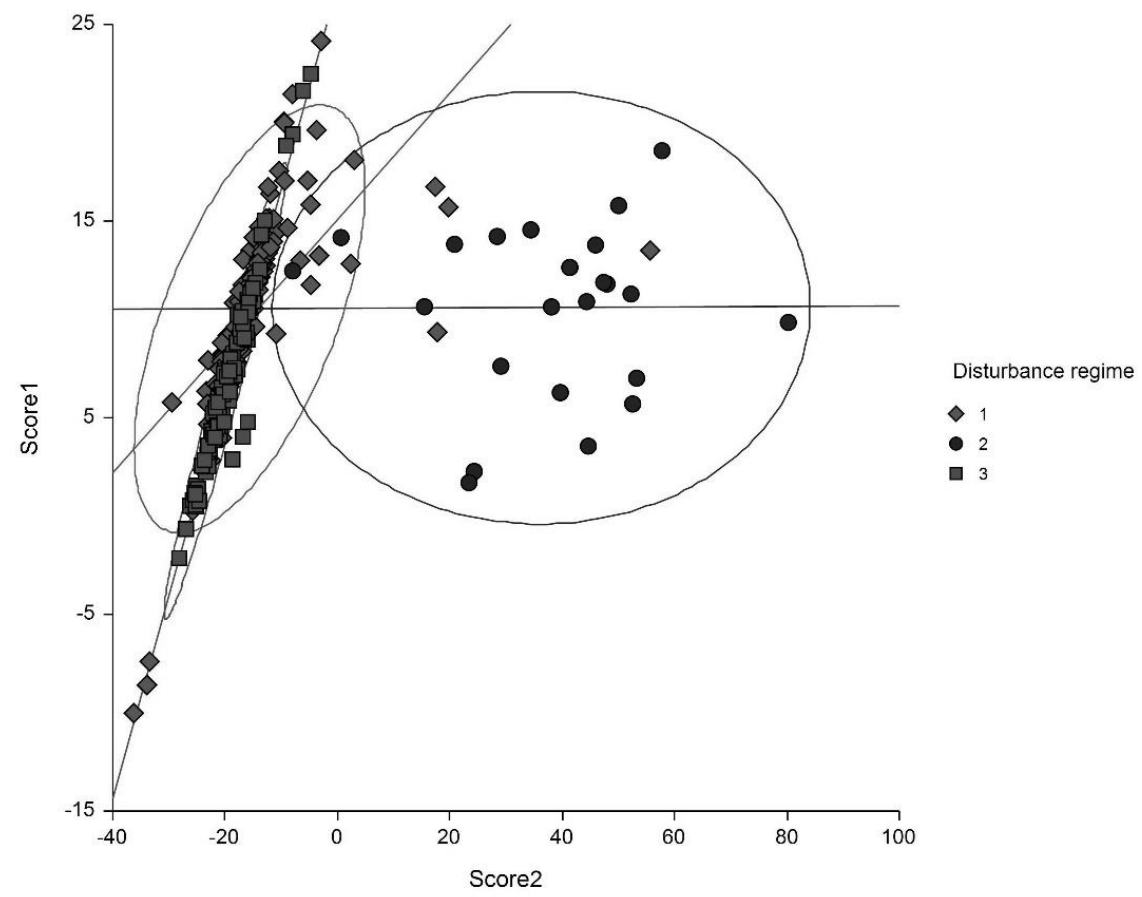

Fig. 6. Graph Linear-Discriminant score 1 vs score 2 for 3 types of habitats classified according to the disturbance regime: 1 - disturbed forest ecosystems after wind calamity in 2004 (OVL, NEX, CVL and EXT, ); 2 - forest ecosystems without disturbances (REF); 3 - disturbed forest ecosystems after wind calamity in 2004 and forest fire in 2005 (FIR1A and FIR3A) and 6 discriminators (see explanations to Table 2).

Table 3. Results of classification of research plots with different disturbation regime by canonical correlation analysis using discriminant functions

\begin{tabular}{lllllll}
\hline Fn & $\begin{array}{l}\text { Canonical } \\
\text { correlation } \\
\text { coefficient }\end{array}$ & F-value & $\begin{array}{l}\text { Numenator } \\
\text { DF }\end{array}$ & $\begin{array}{l}\text { Denominator } \\
\text { DF }\end{array}$ & P-Prob & $\begin{array}{l}\text { Wilks' } \\
\text { Lambda }\end{array}$ \\
\hline 1 & 0.86 & 157.5 & 12 & 1,188 & $<0.001$ & 0.148 \\
2 & 0.65 & 87.2 & 5 & 595 & $<0.001$ & 0.577 \\
\hline
\end{tabular}

Fn, discriminant function (canonical root).

development the species diversity of the tree layer (PD $\mathbf{E}_{3}$ ) and the herbaceous layer (NPS $\mathbf{E}_{1}$ ) increased. The abundance of $M$. agrestis grew in direct proportion to the species richness gradient of the herbaceous layer (NPS $\left.\mathbf{E}_{1}\right)$.

The abundance fluctuation curves of two dominant small rodent species (C. glareolus and $M$. agrestis) (GLM: $F=140.4 ; P<0.001$ and $F=12.5 ; P=0.019)$ and one dominant insectivore $(S$. araneus) were identical in shape (GLM: $F=43.0 ; P=0.002$ ). Initially, the abundance of these small mammals grew concurrently with increasing vegetation coverage, but after an inflection point of higher coverage $(>80 \%)$, it showed a tendency to decrease. The response of the insectivore $S$. minutus to post-disturbance increases in vegetation coverage was not as significant (GLM: $F=4.7 ; P=0.090$ ) as in the above-mentioned species. The rodent $A$. flavicollis responded to increasing vegetation coverage during succession by declining in abundance (GLM: $F=8.8 ; P=0.034$ ) (Fig. 8).
The species-specific responses of small mammals to gradually changing species richness in the individual vegetation strata (Fig. 9) were similar for most of the small mammal species studied. In early stages of plant succession with moderate species richness, we observed a slight decrease in the abundances of the following small mammal species: $S$. araneus, $M$. agrestis, A. flavicollis and $S$. minutus (GLM: $F=138.49 ; P=0.019$ ) (Fig. $6 a)$. Toward the end of the monitoring period, when the species richness of vegetation was higher, the abundance of these species showed an upward trend. However, $C$. glareolus responded with a slight growth in numbers to a low number of plant species, with a further increase for the initial and middle values of plant species richness and a remarkable decline in the late succession stages, where there were the highest numbers of plant species, for all study communities in the same time and space (Fig. 10). 


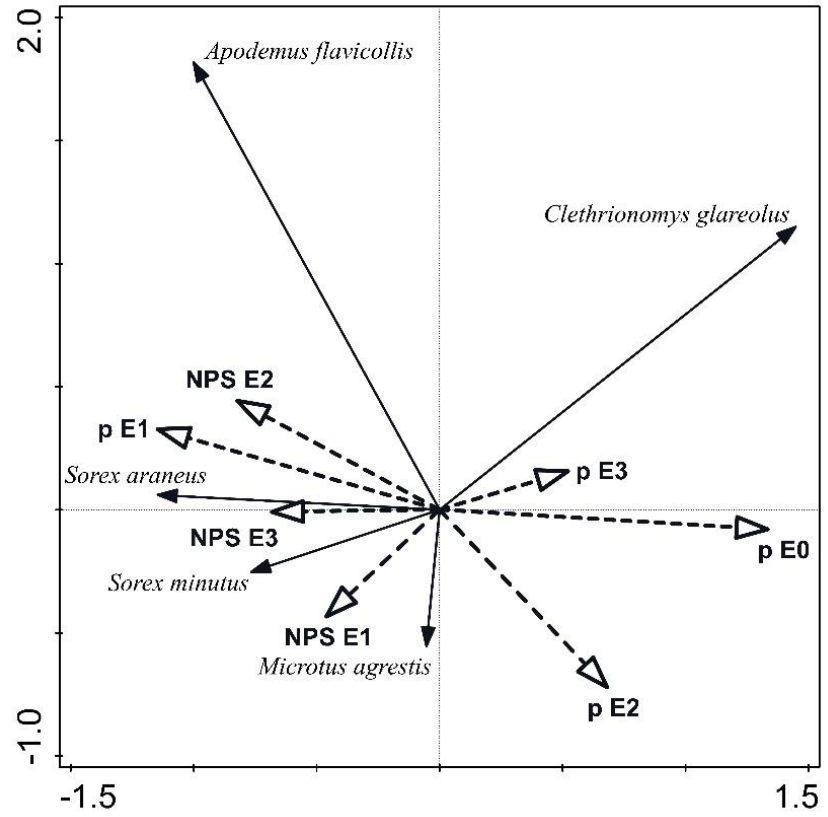

Fig. 7. Ordination diagram showing the first two axes of redundancy analysis (RDA) data on habitat preferences of dominant small mammalian species after disturbance. Species data: abundance of small mammals; environmental variables: data on cover and species richness of vegetation profile ( $\mathrm{p}$ E1 - cover of herbaceous layer; $p$ E2 - cover of shrub layer; $p$ E3 - cover of tree layer; p E0 - cover of moss layer; NPS E1 - number of species of herbaceous layer; NPS E2 - number of species of shrub layer; NPS E3 - number of species of tree layer).

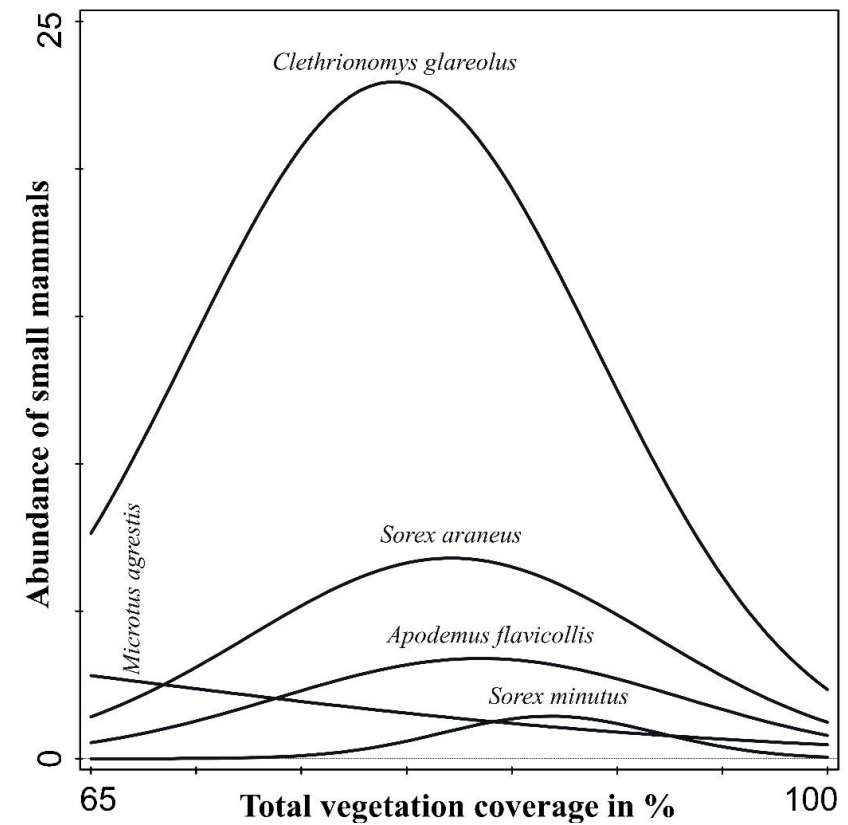

Fig. 8. Species-specific responses of small mammals to temporal and spatial changes in total vegetation coverage following a disturbance in 2007-2016. 


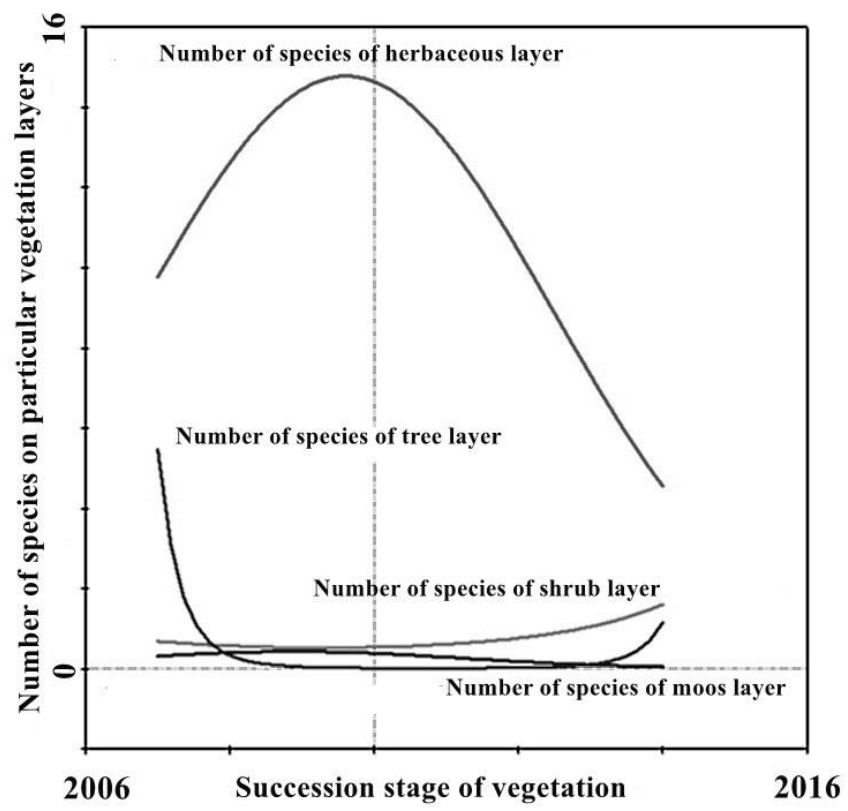

Fig. 9. Changes in species richness in vegetation layers during secondary succession in forest communities following a disturbance in 2007-2016.

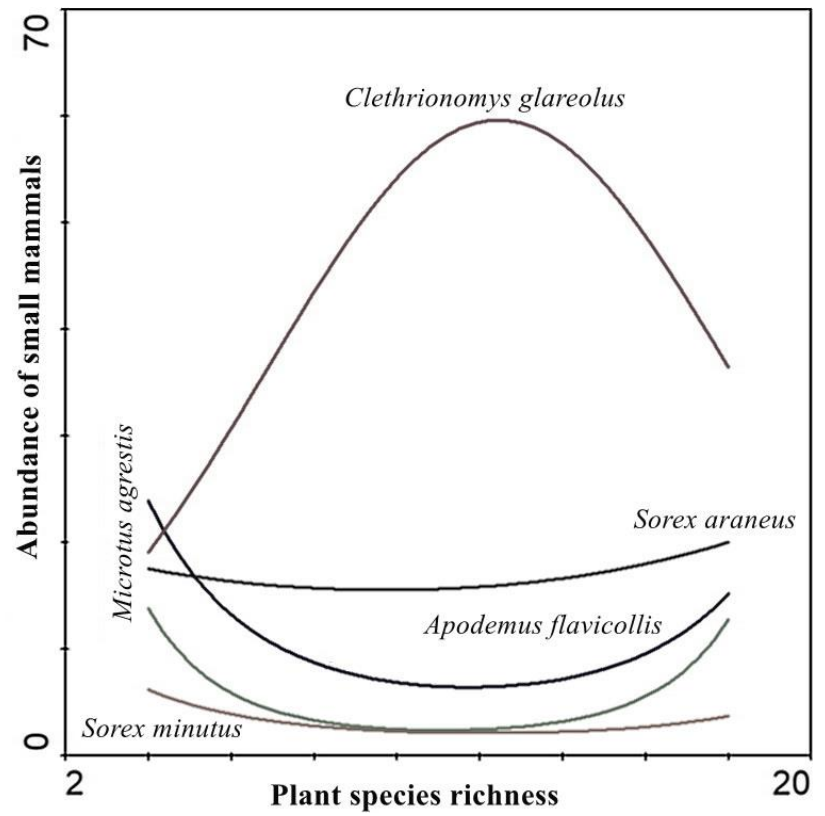

Fig. 10. Species-specific responses of small mammals to temporal and spatial changes in plant species richness following a disturbance in 2007-2016. 


\section{Discussion}

The abundance of small mammals reached the highest level in disturbed habitats during the first years of secondary succession: 4 years after a disturbance we noticed a decrease in abundance, especially in small rodent populations. An increase in abundance in the early stages and a decline in late stages of succession development were documented in three dominant species (A. flavicollis, $C$. glareolus and $S$. araneus), opportunists that successfully settle as the first habitats after a disturbance. The analysis of the data obtained by us showed that more specialized species of small mammals ( $M$. avellanarius, $M$. minutus, $S$. betulina, $N$. fodiens, $N$. anomalus, $S$. minutus) with overall lower abundances start to be present in small mammal communities up to 5-6 years after disturbance, which is probably related to increasing habitat heterogeneity during secondary vegetation succession. Different patterns of responses of generalist and specialized small mammal species to different levels of disturbance in Europe's forest ecosystems have also been revealed by an analysis of a large data set by BoGDZIEWICZ and ZWOLAK (2014). Because the complexity of an environment is a temporal function, we consider the succession age of the disturbed habitat to be a key factor of secondary succession, which significantly modifies the complexity of the environment and relates to changes in the abundance of small mammals. Rapid changes in vegetation over the first 5 years of secondary succession confirms the work of DANIELSON and ANDERSON (1999). Those authors examined the relationship between the succession age of the habitat and relative abundance of a species. Their results indicated the abundance of highly specialized species of small mammals decreases significantly with increasing habitat age.

Succession changes in the communities we studied were the greatest in the early stages; later, the rate of succession changes decreased and differences in the diversity of small mammal species on the areas affected by a disturbance were levelled. The results of our research suggest that the species richness of small mammal communities in disturbed areas (NEX, EXT, FIR1A, FIR3A, CVL, OVL) gradually increases in the first 8 years after disturbance (2004-2013), decreases in the next phase of the succession series (after 2013), and reaches its minimum at the end of the observed period (2014-2016). During the entire research period (2005-2016), the communities of small mammals of larch-spruce forests in the terminal phase of succession of forest communities showed the lowest species richness (REF area without disturbances). This is consistent with the results of several studies (e.g., PANZACCHI et al., 2010; ZÁRYBNICKÁ et al., 2017), whose authors state that the highest species diversity is achieved by small mammals in young forest habitats, i.e. in the initial stages of succession, and vice versa the lowest in its terminal stages (in adult forest stands). The increase in species diversity of small mammals in the early stages of succession is probably related to the increase in structural heterogeneity of habitats (indicated in our study by succession changes in species diversity and vegetation cover), consistent with the habitat heterogeneity hypothesis (MACARTHUR, 1961).
This hypothesis was also supported by other research focused on the study of successive (BoLLINGER, 1995) and disturbed habitats (KROJEROvá-ProKEŠOví et al., 2016). The significant influence of vegetation parameters on changes in small mammalian species groups is also noted by PANZACCHI et al. (2010). In general, in habitats with a higher number of plant species, there are more rodent species (more diversified food sources, antipredation shelter) and insectivores (higher insect biodiversity), as stated in the study WANG et al. (2001).

Vegetation structure and its changes during succession affect succession changes in small mammal communities (Thompson and Gese, 2013). The succession stage of vegetation in the study plots affected by a disturbance influenced the structure of small mammal communities through changes in the species composition and both the horizontal and vertical structures of the vegetation profile, expressed by gradients of species richness and abundance in individual vegetation layers. The highest abundance was reached in plots with a total vegetation coverage of about $80 \%$. In research plots with higher coverage, we observed a decrease in abundance, especially in dominant rodent species. Small mammals, especially rodents, are directly influenced by vegetation. The species diversity of rodents negatively correlates with vegetation height and coverage (ZHANG et al., 2018).

Based on a detailed analysis of the data obtained on postdisturbance succession of small mammal communities, we assume that due to the increasing frequency of intensity and extent of disturbances in forest ecosystems of the Carpathian arc, there will be faster and more frequent changes affecting the population density and small mammals, but also their ecological and spatiotemporal distribution. In connection with such largescale disturbances of forest ecosystems in the future, we can expect the development of new adaptations and life strategies in local small mammal populations, as well as changes in their habitat selection and food preferences.

\section{Acknowledgements}

The authors thank Dr. Martin Korňan from the Department of Applied Zoology and Wildlife Management Technical University in Zvolen and Dr. Ján Topercer from the Botanical Garden of Comenius University in Blatnica for consultations regarding the statistical methods used. This project was funded by the Research Station and the TANAP Museum as a part of a long-term study of forest ecosystems affected by wind calamity and fire and by the Grant VEGA No. 2/0012/19 'Animals in the forest ecosystems and urban environment in the context of the local and global changes'.

\section{References}

Balčiauskas, L., Čepuklené, A., BalČiaukiené, L., 2017. Small mammal community response to early meadowforest succession. Forest Ecosystems, 4: 4-11. DOI 
10.1186/s40663-017-0099-6

Balshi, M.S., McGuire, A.D., Zhuang, Q., Melillo, J., Kicklighter, D.W., Kasischke, E., Wirth, C., Flannigan, M., Harden, J., Clein, J.S., Burnside, T.J., McAllister, J., Kurz, W.A., ApPs, M., ShVidenKo, A., 2007. The role of historical fire disturbance in the carbon dynamics of the pan-boreal region: a process-based analysis. Journal of Geophysical Research, 112: 1-18. https://doi.org/10.1029/2006JG000380

Beauvais, G.P., BusKiRK, S.W., 1999. Modifying estimates of sampling effort to account for sprung traps. Wildlife Society Bulletin, 27: 39-43.

Bogdziewicz, M., Zwolak, R., 2014. Responses of small mammals to clear-cutting in temperate and boreal forests of Europe: A meta-analysis and review. European Journal of Forest Research, 133: 1-11. https://doi.org/10.1007/ s10342-013-0726-x

Bollinger, E. K., 1995. Successional changes and habitat selection in hayfield bird communities. Auk, 112 (3): 720-730.

Chapin, F.S., McGuire, A.D., Randerson, J., 2000. Arctic and boreal ecosystems of western North America as components of the climate system. Global Change Biology, 6: 211-223. https://doi.org/10.1046/j.13652486.2000.06022.x

Danielson, J. B., Anderson, G. S., 1999. Habitat selection in geographically complex landscapes. In BARRETT, G.W., Peles J.D., 1999 (eds). Landscape ecology of small mammals. New York, Berlin, Heidelberg : Springer Verlag. $347 \mathrm{p}$.

Franklin, J.F., Spies, T.A., Van Pelt, R., Carey, A.B., Thornburgh, D.A., Berg, D.R., Lindenmayer, D.B., Harmon, M.E., Keeton, W.S., Shaw, D.C., Bible, K., CHeN, J., 2002. Disturbances and structural development of natural forest ecosystems with silvicultural implications, using Douglas-fir forests as an example. Forest Ecology and Management, 155: 399-423. https://doi.org/10.1016/ S0378-1127(01)00575-8

Gardiner, B., Blennow, K., Carnus, J. M., Fleischner, P., Ingemarson, F., Landmann, G., Lindner, M., Marzano, M., Nicoll, B., Orazio, C., Peyron, J.L., Reviron, M.P., SchelhaAs, M., Schuck, A., Spielmann, M., UsBeck, T., 2010. Destructive storms in European forests: Past and forthcoming impacts. Final report to European Commission - DG Environment. Joensuu: European Forest Institute, Atlantic European Regional Office, EFIATLANTIC, Cestas. 137 p.

HanzÁk, J., RosickÝ, B., 1949. New findings about some representatives of the orders Insectivora and Rodentia in Slovakia. Sbornik Národního Musea v Praze, Acta Musei Nationalis Pragae, no. 4: 3-77.

HlôšKa, L., Chovancová, B., Chovancová, G., Fleischer, P., 2016. Influence of climatic factors on the population dynamics of small mammals (Rodentia, Soricomorpha) on the sites affected by windthrow in the High Tatra Mts. Folia Oecologica, 43 (1): 12-20.

KowALSKI, K., 1957. Microtus nivalis (Martins, 1842) (Rodentia) in Carpathians. Acta Theriologica, 1 (6): 159182 .

Kowalski, K., 1960. Pitymys Mc. Mutrie 1831 (Microtidae, Rodentia) in the Northern Carpathians. Acta Theriologica, 4 (6): 81-89.
Kratochvíl, J., 1968. Der Antritt des Vermehrungsprozesses der kleinen Erdsäugetiere in der Hohen Tatra. Zoological Letters, 17: 299-310.

Kratochvíl, J., 1970. Pitymys-Arten aus der Hohen Tatra (Mammalia, Rodentia). Acta Science Naturae Brno, 4: $1-63$.

Kratochvíl, J., Gaisler, J., 1967. Die Sukzession der kleinen Erdsäugetiere in einem Bergwald Sorbeto-Piceetum. Zoological Letters, 16: 301-324.

Kratochvíl, J., Pelikán, J., 1955. Notes on the penetration of field voles into the Tatra National Park. Zoological and Entomological Letters, 4: 303-312.

KreBs, C.J., 1966. Demographic changes in fluctuating populations of Microtus californicus. Ecological Monographs, 36: 239-273.

Krojerová-Prokešová, J., Homolka, M., Barančeková, M., Heroldová, M.,., Baňař, P., Kamler, J., Purchart, L., Suchomel, J., ZeJdA, M., 2016. Structure of small mammal communities on clearings in managed Central European forests. Forest Ecology and Management, 367: 41-51. https://doi.org/10.1016/j.foreco.2016.02.024

Li, X., He, H.S., Wu, Z., Liang, Y., Schneiderman, J.E., 2013. Comparing effects of climate warming, fire, and timber harvesting on a boreal forest landscape in northeastern China. PLoS One, 8: e59747. https://doi. org/10.1371/journal.pone.0059747

Lindner, M., MaroscheK, M., Lindner, M., MaroscheK, M., Netherer, S., Kremer, A., Barbati, A., GarciaGonzalo, J., Seidl, R., Delzon, S., Corona, P., Kolström, M., LeXer, M.J., Marchetti, M., 2010. Climate change impacts, adaptive capacity, and vulnerability of European forest ecosystems. Forest Ecology and Management, 259: 698-709. https://oi. org/10.1016/j.foreco.2009.09.023

MacArthur, R., MacArthur, J.W., 1961. On bird species diversity. Ecology, 42 (3): 594-598. https://doi. org/10.2307/1932254

Meddens, A.J.H., Hicke, J.A., Ferguson, C.A., 2012. Spatiotemporal patterns of observed bark beetle-caused tree mortality in British Columbia and the western United States. Ecological Applications, 22: 1876-1891.

Meloun, M., MilitkÝ, J., Hill, M., 2017. Statistická analýza vicerozmerných dat $v$ príkladech [Statistical analysis of multidimensional data in examples]. Praha: Karolinum. $757 \mathrm{p}$.

NCSS 9 Statistical Software (2013). Kaysville, Utah, USA: NCSS LLC. [cit. 2021-05-10]. ncss.com/software/ncss.

Niedzialkowska, M., Konczak, J., Czarmonska, S., 2010. Species diversity and abundance of small mammals in relation to forest productivity in northeast Poland. Ecoscience, 17 (1): 109-119. https://doi.org/10.2980/17$1-3310$

Panzacchi, M., Linnell, J.D.C., Melis, C., Odden, M., Odden, J., Gorini, L., Andersen, R. 2010. Effect of land-use on small mammal abundance and diversity in a forest-farmland mosaic landscape in south-eastern Norway. Forest Ecology and Management, 259: 15361545. https://doi.org/10.1016/j.foreco.2010.01.030

Pelikán, J., 1955. About the state of some small mammals in the High Tatras in the spring of 1955. Zoological and Entomological Letters, 4: 295-302. 
Reichstein, M., Bahn, M., Ciais, P., Frank, D., Mahecha, M.D., Seneviratne, S.I., Zscheischler, J., Beer, C., Buchman, N., Frank, D.C., Papale, D., Smith, P., Thonicke, K., VAn der Velde, M., Vicca, M., Walz, A., WatTENBACH, M., 2013. Climate extremes and the carbon cycle. Nature, 500: 287-295. https://doi.org/10.1038/ nature 12350

Sánchez-GonzÁlez, B., Barja, I., Navarro-Castilla, Á., 2017. Wood mice modify food intake under different degrees of predation risk: Influence of acquired experience and degradation of predator's faecal volatile compounds. Chemoecology, 27: 115-122. https://doi.org/10.1007/ s00049-017-0237-1

SeIDL, R., SchellhaAs, J.M., LeXer, J.M., 2011. Unraveling the drivers of intensifying forest disturbance regimes in Europe. Global Change Biology, 17 (9): 2842-2852. https://doi.org/10.1111/j.1365-2486.2011.02452.x

SchelhaAs, M. J., NabuURs, G. J., SchuCK, A., 2003. Natural disturbances in the European forests in the 19th and 20th centuries. Global Change Biology, 9: 1620-1633. DOI: 10.1046/j.1529-8817.2003.00684.x

Seidl, R., Schellhaas, J. M., Rammer, W., Verkerk, J. P., 2014. Increasing forest disturbances in Europe and their impact on carbon storage. Nature Climate Change, 4 (9): 806-810. https://doi.org/10.1038/nclimate2318

Šmilauer, P., LePš, J., 2014. Multivariate analysis of ecological data using Canoco 5. Cambridge CB2 8BS, United Kingdom: University Printing House. 360 p.

Štollmann, A., Dudich, A., 1985. Contribution to the knowledge of the fauna of small terrestrial mammals (Insectivora, Rodentia) of the Western Tatras. Zbornik prác o Tatranskom národnom parku, 26: 161-172.

Temperli, C., Bugmann, H., Elkin, C., 2013. Cross-scale interactions among bark beetles, climate change and wind disturbances: A landscape modeling approach. Ecological Monographs, 83: 383-402. https://doi.org/10.1890/121503.1
Thompson, C.M., GeSE, E.M., 2013. Influence of vegetation structure on the small mammal community in a shortgrass prairie ecosystem. Acta Theriologica, 58: 55-61.

Turner, M.G., 2010. Disturbance and landscape dynamics in a changing world. Ecology, 91: 2833-2849. https://doi. org/10.1890/10-0097.1

UMETSU, F., PARDINI, R., 2007. Small mammals in a mosaic of forest remnants and anthropogenetic habitats-evaluating matrix quality in a Atlantic forest landscape. Lanscape Ecology, 22: 517-530. https://doi.org/10.1007/s10980006-9041-y

Wang, G. M., Zhou, Q.Q., Zhong, W.Q., Sun, C.L., Chen, Z.Z., 2001. Species richness - primary productivity relationship of plants and small mammals in the Inner Mongolian steppes, China. Journal of Arid Environments, 49: 477-484. https://doi.org/10.1006/jare.2001.0814

Westerling, A.L., Hidalgo, H.G., CaYan, D. R., Swetnam, T.W., 2006. Warming and earlier spring increase western U.S. forest wildfire activity. Science, 313: 940-943. DOI: 10.1126/science. 1128834

ZÁrybnická, M., Riegert, J., Bejček, V., Sedláček, F., ŠŤastný, K., Šindelář, J., Heroldová, M., Vilímová, J., ZIMA, J., 2017. Long-term changes of small mammals communities in heterogenous landscapes of Central Europe. European Journal of Wildlife Research, 63 (6): 1612-1642. https://doi.org/10.1007/s10344-017-1147-9

Zhang, M., Wang, Y., Li, B., Feng, Z., ZhaO, Y., Xu, Z., 2018. Synergistic succession of the small mammal community and herbaceous vegetation after reconverting farmland to seasonally flooded wetlands in the Dongting Lake Region, China. Mammal Study, 43 (4): 229-243. https://doi.org/10.3106/ms2017-0043

Zuur, F. A., Ieno, N. E., Smith, M. G., 2007. Analysing ecological data. New York: Springer Science + Busines Media, LLC. 672 p.

Received June 1, 2021

Accepted October 4, 2021 